\title{
BENZENE POISONING AS A POSSIBLE CAUSE OF TRANSVERSE MYELITIS
}

By P. Herregods, M.D., R. Chappel, M.D. and G. Mortier, M.D.

Service of Physical Medicine and Rehabilitation, Middelheimziekenhuis, Antwerp, Belgium

Summary. A case of transverse myelitis in a 25 -year-old patient was described. The transverse myelitis was caused by toxic cause, probably as a result of benzene poisoning. This diagnosis was based on:

I. The differential diagnosis.

2. The patient's occupation.

3. The abnormal high urinary phenol levels.

4. The coincidence of decreasing urinary phenol values with an amelioration of the clinical condition of patient.

After consulting the literature, we think that this case of transverse myelitis based on a benzene poisoning is the first ever described.

Key words: Transverse myelitis; Benzene poisoning; Tetraplegia.

\section{Case Report}

A 25-YEAR-OLD warehouseman, working at a wholesale supplier of chemicals and druggist's materials, was admitted into the hospital with the following complaints. In the morning at his work the patient felt an acute interscapular pain, also radiating down to both arms. Thereafter a progressive paresis of both legs appeared, so that around midday he was unable to rise to his feet. In the afternoon the paresis spread to both upper limbs. At the same time he was unable to urinate spontaneously. This complete picture developed after about ro hours.

There were no medical precedents, neither personal nor in the family. On clinical examination we found a conscious patient in good general condition, temperature $36 \cdot 2^{\circ} \mathrm{C}$, normal pulse, blood pressure $120 / 70 \mathrm{mmHg}$, normal heart auscultation and abdominal breathing.

On neurological examination the following signs were found:

I. Complete paralysis of the lower limbs, the hand and forearm muscles, and paresis of the upper arms muscles, more pronounced on the right side.

2. Hypotonic muscles in the four limbs.

3. Paresthesias and sensory distortion from the level of $D_{1}$.

4. Bladder and bowel dysfunction; on admission $\mathrm{I} \cdot 250 \mathrm{ml}$ urine was obtained.

5. Normal functioning of the cranial nerves with absence of any neck stiffness. Negative Lasègue sign. Isocorias. Normal reflexes to light.

6. Weak bilateral peripheral reflexes in the four limbs. No Babinski's sign.

On the basis of the clinical picture the patient was admitted to hospital 
with the tentative diagnosis of Guillain-Barré Syndrome with ascending paralysis and sphincter disturbances (Landry's type). Lumbar punctures were carried out, the first cerebrospinal fluid study revealing a normal glucose level, increase of the protein content ( $79 \mathrm{mg}$ per cent) and a pleocytosis of ro30 red cells. A traumatic puncture was supposed. At a second puncture the glucose and protein levels were normal. A low pleocytosis (IO white cells $/ \mathrm{mm}^{3}$ ) was observed. In the meantime the following results were reported: sedimentation rate $18 \mathrm{~mm}$ first hour, haemoglobin I I $2 \mathrm{~g} / \mathrm{dl}$, haematocrit 0.32 , erythrocyte count $3820000 / \mathrm{mm}^{3}$, leucocyte count $8400 /$ $\mathrm{mm}^{3}$, platelets $190000 / \mathrm{mm}^{3}$ and normal bloodcount. The cerebrospinal fluid study of the third lumbar puncture revealed no cells with normal protein and glucose levels. Similarly no increase of the $\gamma$-globulin fraction in the cerebrospinal fluid was noted.

A cervical myelography was carried out, also an arteriogram of the artery of Adamkiewicz, of the vertebral artery and its cervical arteries. No vascular abnormalities of external or internal origin was found.

Also viral tests were carried out including adeno-, cytomegalo-, coxackie and herpes simplex virus, Eaton agent, $Q$ fever, ornithosis, influenza and parainfluenza. The viral serology was negative, including the control examination. In view of the patient's job a toxicological examination was requested. The results of hippic acid, methylhippic acid, acetic acid and trichlorethylen were all normal. Only a high level of urinary phenol $(28 \mathrm{mg} / \mathrm{l}$; normal value less than $\mathrm{I}$ o $\mathrm{mg} / \mathrm{l}$, toleration rate $20 \mathrm{mg} / \mathrm{l}$ ) was noted.

After about 6 weeks the clinical picture changed from a flaccid into a spastic tetraparesis with sphincteric and sensory disturbances. The electromyography suggested a medullary disease (level $\mathrm{C}_{7}-\mathrm{C}_{8}-\mathrm{D}_{1}$ ) with strong loss of motor units and already partial recovery. The evoked potentials suggested an intramedullary injury $\mathrm{C}_{7}-\mathrm{C}_{8}-\mathrm{DI}_{1}$, which was evident by the SEP ( = sensory evoked potentials), of the upper limbs with delayed plexus conduction velocities of both ulnar nerves and considerably disturbed cervicosubcortical and cortical potentials of both ulnar nerves. The SEP of the lower limbs were normal.

A control toxicological examination still revealed a phenol level of $27 \mathrm{mg} / \mathrm{l}$. After 4 months the patient was discharged from the hospital with normal muscle strength of the upper limbs, a spastic paraparesis of the lower limbs, bladder dysfunction and paresthesias starting from the level C8-Di. A nearly normal gait, with two crutches however, was already possible.

On discharge the phenol level was measured a third time and amounted to $17 \mathrm{mg} / \mathrm{l}$.

Three months after discharge from the hospital a control ambulatory examination showed the following symptoms:

I. Sensibility: increasing parethesias from DI, probably indicating further recovery.

2. Power: normal muscle strength of the upper limbs, normal muscle strength of the lower limbs, excluding the feet extensors (grade 3 of of the Lovett scale). The patient was able to walk without crutches and even to mount some stairs.

3. Increased tendon reflexes with clonus more pronounced at the right side. 
4. Bladder dysfunction. The patient could still not micturate spontaneously but urinated with bladder tapping and Crédé's method. Residual urine of about 0 to $\mathrm{IO} \mathrm{ml}$.

5. Phenol level. The urinary phenol level amounted to $4 \mathrm{mg} / \mathrm{l}$, which is a normal value.

\section{Discussion}

As a final diagnosis we considered the most likely one to be transverse myelitis based on poisoning, more particularly by benzene.

There were many reasons for this.

\section{The Differential Diagnosis}

On admission into hospital we noted:

(a) a flaccid tetraplegia with sensory and sphincteric disturbances

(b) a slight anaemia with haemoglobin I I.3 g/dl, haematocrit 0.32 , erythrocyte count 3820000 . We checked the haemoglobin and erythrocytes one week after the onset of the tetraplegia and found normal values.

(c) a slightly increased sedimentation rate, i.e. $18 \mathrm{~mm}$ first hour.

In the first instance a Guillain-Barré syndrome was suggested. An albuminocytological dissociation by lumbar puncture could not be demonstrated on examination. The further clinical evolution, characterised by an increased spasticity, definitively excluded this diagnosis.

Multiple sclerosis was rejected as a diagnosis because of the results of the evoked potentials and because the $\gamma$-globulins fraction in the cerebrospinal fluid showed no increase.

A vascular malformation and a compression of the cervical spinal cord was excluded. The arteriogram of the artery of Adamkiewicz and the arteriogram of the arteria vertebralis and its spinal arteries were normal as well as the cervical myelography with amipaque.

Transverse myelitis was indicated as the final diagnosis. The aetiology is viral in two-thirds of the cases but in this case was excluded as the viral aetiology was on two occasions normal. Other possible causes of transverse myelitis, such as a vertebral dislocation with or without fracture, haematomyelia, spinal contusion, syphilis, tuberculosis, spinal epidural abscess, polyarteritis nodosa, multiple sclerosis, adhesive spinal arachnoiditis, cervical spondylosis, sarcoidois, bacterial infection, syringomyelia or spinal cord tumours were excluded by the patient's history and the investigations carried out. By eliminating all other possible diagnoses which could possibly explain this clinical history, we decided upon transverse myelitis on a toxicological basis as the final diagnosis.

\section{Patient's Occupation}

A second argument supporting our diagnosis was the patient's occupation. He was a warehouseman working in wholesale supply of chemicals and druggist's materials. Professionally he was therefore every day in direct 
contact with benzene and its derivatives (Browning, I965; Carpenter, I949; Gerarde, I959; Lauwereys, I972; Plunkett, I966).

Benzene is widely used in industrial processes, of which the most important at the present are:

(a) Constituent element of aircraft- and motorcar fuel.

(b) Basic material for the production of plastics, paints, pesticides, drugs, rubber, raincoats, etc.

(c) Solvents for paints, inks, lacquers.

\section{The Urinary Phenol Level (Browning, 1965; Lauwereys, I972)}

The only pathological laboratory finding was an increased phenol level.

The presence of a high quantity of phenol in the urine while renal function is normal indicates benzene poisoning. Benzene can be absorbed into the bloodstream and the tissues by inhalation, ingestion and after topical application to the intact skin. The most important is by inhalation.

The metabolism of benzene can be explained as follows:

(a) Partly breathed out unchanged ( +40 per cent).

(b) Partly metabolised in phenols, which in the liver are conjugated with sulphteion or glucuron acid. These metabolites are eliminated by the urinary tract.

(c) Partly conjugated with glutathion.

Benzene therefore can be detected by a quantitative determination of phenol in the urine (as happened with our patient), or by determining the proportion of inorganic versus organic urinary sulphates. According to the literature this last test is less accurate although the phenol test could also be criticised. Indeed, normal liver and renal functions are necessary to obtain significant results, however, this was the case with our patient. The phenol tests on our patient were carried out in a laboratory of toxicology, where detection of phenol was carried out by chromatography. First the urine sample was hydrolysed and thereafter microsteam distillation was performed in a suitable apparatus. After this procedure chromatogaphy was used for determination of free phenol. The normal value is less than Io $\mathrm{mg} / \mathrm{l}$ and the toleration rate is $20 \mathrm{mg} / \mathrm{l}$.

Other frequent laboratory values (Gerarde, 1959) which would suggest benzene poisoning, as for instance a leucocyte count below $4000 / \mathrm{mm}^{3}$, an erythrocyte count below $4000000 / \mathrm{mm}^{3}$, platelets less than $100000 / \mathrm{mm}^{3}$, a haemoglobin content of less than $12 \mathrm{~g} / \mathrm{dl}$ and the increase of immature erythrocytes were not present.

Greenburg (1939) stated that those alterations of the normal blood picture are not necessarily present. This could explain that the increased urinary phenol level was the only pathological laboratory finding.

\section{Toxicology}

A distinction is usually made between acute and the chronic toxicity by benzene (Browning, I965; Gerarde, I960; Lauwereys, I972; Plunkett, I 966). 


\section{(a) Acute Intoxication}

An acute intoxication causes excitement, incoherent speech, vertigo, insomnia, nausea and paresthesias in mild cases. In more severe cases, or after a long exposure to benzene, we find convulsions, coma and even death. The most important causes of death are respiratory paralysis, pulmonary oedema and haemorrhage, or a combination of these factors.

\section{(b) Chronic Intoxication}

The result of benzene poisoning in such a case is bone marrow injury. The amount of damage varies from person to person, and from the latency period between the exposure to benzene and the appearance of the first symptoms. Classically, we can detect aplasia of the bone marrow with a thrombopaenia $\left(<\mathrm{I00000} / \mathrm{mm}^{3}\right)$, a leucopaenia $\left(<4000 / \mathrm{mm}^{3}\right)$, an anaemia $(<4000000 /$ $\mathrm{mm}^{3}$ ) and an increase of immature erythrocytes. Only after the appearance of these pathological findings will clinical symptoms appear, secondary to these abnormal laboratory values. With a decrease of platelets purpura, menorrhagia and epistaxis will develop, the decrease of granulocytes causing angina, stomatitis, gingivitis, etc. Sometimes there is a hyperplastic reaction of the bone marrow, deteriorating into a leucaemia for which the prognosis must be most guarded. The neurotoxicity of benzene can be described as follows. The aromatic hydrocarbons have a particular affinity for nerve tissue because of their high lipid content. The presence of benzene in the nerve cells interferes with their normal metabolism, both in the brain as in the spinal cord.

Normal metabolic activity and full functions only return after the complete elimination of the aromatic hydrocarbons. However, this effect occurs slowly because of the high lipid solubility of the hydrocarbons.

The neurotoxicity (Gerarde, 1959; Gerarde, 1960; Hine, 1954) of the aromatic hydrocarbons is believed to be a consequence of haemorrhage in the nerve system, principally in the grey matter of the cervical and thoracic spinal cord.

These haemorrhages are believed to be the result of local irritation of endothelial cells of the blood vessels, resulting in permeability changes in the capillaries. This in turn leads to increased diapedesis, oedema in surrounding tissues, petechial and gross haemorrhage. Animal experiments showed a paralysis of the extremities with final destruction of the nerve cells. Concerning the toxic effect on the nerve tissues Hine (I954) commented as follows, 'On reviewing the literature we were surprised to find no reference to detailed studies of central system lesions produced by benzene'.

\section{Conclusions}

The above-mentioned information, as well as the coincidence of decreasing phenol values $(28 \mathrm{mg} / 1,27 \mathrm{mg} / \mathrm{l}, 17 \mathrm{mg} / 1,4 \mathrm{mg} / 1$ respectively I week, I month, 3 months and 6 months), after the benzene poisoning, with an amelioration of the tetraplegia as described, is an additional argument in favour of our final diagnosis.

After consulting the literature on this subject we also think that this 
aspect of benzene poisoning in a clinical case has never been commented upon previously.

\section{Acknowledgement}

\section{We would like to thank Mrs G. Ceurrmons-Speybrouck for her cooperation with the translation of the original manuscript.}

\section{RÉSUMÉ}

Un cas d'une myelite transverse chez un patient de vingt-cinq ans est présenté. La myelite transverse était probablement causée par une intoxication par le benzol. Ce diagnostic était basé sur:

I. Le diagnostic différentiel.

2. La profession du patient.

3. Les valeurs abnormalement élevées du phénol urinaire.

4. La concordance entre la diminution des valeurs de phénol urinaire avec l'amélioration clinique du patient.

Nos recherches dans la litérature spécialisée nous font penser que le cas présent est la premiére description d'une myélite transverse causée par le benzol.

\section{ZUSAMMENFASSUNG}

Die Kasuistik einer Myelitis transversa bei einem 25-jährigen Mann wird berichtet. Die Myelitis transversa war möglich verursacht durch eine Benzeenintoxikation. Diese Diagnose gründet sich auf:

I. Die Differentialdiagnose.

2. Den Beruf des Patientes.

3. Den abnormal hohen urinären Phenolwerten.

4. Die Zurückbildung der Symptome gleichzeitig mit diesen der urinären Phenolwerte.

$\mathrm{Er}$ is uns nicht gelungen einen anderen Fall von Myelitis transversa nach Benzeenintoxikation in die Literatuur zurückzufinden.

\section{REFERENCES}

Browning, E. (1965). Toxicity and metabolism of industrial solvents. Elsevier, pp. I-65.

CARPENTER, C. (I949). The assay of acute vapor toxicity and the grading and interpretation of results on 96 chemical compounds. Fournal of Hyg. Toxicol., 31, 343-346.

GREENBURG, L. (I939). Benzen poisoning in the rotogravure printing industry in New York City. Fournal of Indian hyg. toxicol., 21, 395-420.

Gerarde, H. W. (I959). Toxicological studies on hydrocarbons. Archives of Industrial Health, 19, 403-418.

Gerarde, H. W. (1960). Toxicology of aromatic hydrocarbons. Elseviers Monographs.

HrNe, C. H. (1954). Toxicological studies on p-tertiary-butyltoluene. Archives of Industrial Health, 9, 227-244.

LauWEREys, R. (1972). Précis de Toxicologie industrielle et des intoxications professionnelles. Duculot Gembloux, pp. 23 I-247.

Plunketr, E. R. (1966). Industrial Toxicology. Chemical Publishing Company, New York, pp. 44-45. 